\title{
Mathematics as an Assessment Tool for the Development of Students' Entrepreneurial Skills in Senior Secondary Schools in Benue State
}

\author{
${ }^{1}$ Akaazua, Jacob. Tertsea PhD., ${ }^{2}$ Akuto, Grace Wandoo PhD \\ ${ }^{1}$ Department of Mathematics Education, University of Agriculture, Makurdi, Benue State, Nigeria \\ ${ }^{2}$ Department of Education Foundation and General Studies, University of Agriculture, Makurdi, \\ Benue State, Nigeria
}

\begin{abstract}
This paper examined the level of Mathematics as an assessment tool for the development of students' entrepreneurial skills in Senior Secondary Schools in Benue Sate. The population of the study consisted of all Senior Secondary School two students in Benue State. The total sample of this study was 208 students drawn using Krejcie \& Morgan (1970) table for determining sample size. The instrument used for data collection was a structured questionnaire which contains 22 items. A survey research design was used for the study. Two research questions were asked and two hypotheses were formulated to guide the study. The research questions were answered using mean and standard deviation while the hypotheses were tested at 0.05 level of significance using chi-square statistical tool. The findings of this study indicated that Mathematics has really been the brain behind every entrepreneurial skill in Nigeria. One of the recommendations made was that, students' should imbibe the spirit of doing-it-yourself which will in turn produce the needed skills for entrepreneurships.
\end{abstract}

\section{Introduction}

An entrepreneur is a person who sets up a business or businesses, taking on financial risks in the hope of profit especially in the entertainment industry. Recently in Nigeria there has been a wide cry of unavailability of jobs by graduates when in every programme of study in our universities there is a Mathematics course unit included in the curriculum content of such a programme. Entrepreneurial skills development as a new subject been emphasized in the Nigerian secondary school curriculum is the process of identifying, developing and bringing a vision or an idea for living (Zuamo and Aondoakaa, 2007). These may be an innovative idea in a school curriculum or simply a better way of doing something. Entrepreneurial skills are important to the growth of any nation.

The role of mathematics to the development of students' entrepreneurial skills in senior secondary schools cannot also be overemphasized. This is because it constitutes necessary assessment tools in the curriculum of any school. For example, the study of geometry especially helps to develop the mind in determining differences at early stages of our life as in games where children are made to place different shapes (squares, rectangles and circles) in the right positions or slots. These help the toddlers to make deductions that expand their mind and are their first exposures to Mathematics for entrepreneurial skills development. The computers also would not have worked without the binary system of one or zero for yes or no respectively. The number systems without which an entrepreneur would not know how to sell for example her yams in three's or tens as in number base three or ten nor can a footballer calculate how to score a goal in an angle at ninety degrees are good example of Mathematics as an assessment tool for the development of students' entrepreneurial skills. These are very powerful examples of mathematics as an assessment tool for the development of entrepreneurial skills. It is on this premise that it is believed that the quality of a nation's entrepreneurial skills development is proportional to the level of its Mathematical assessment tool prosperity. According to a report by Omenka, (2013) mathematics as a key element and activity in the day to day living of every human being is a subject which consists of facts, concepts and entrepreneurial skills which every person whether a layman or business man should know. Omenka (2013) also gave 
an example of the concept of the number system being so fundamental that in our daily lives, no normal human being can function well without it.

Economically, advanced nations of the world are distinguished by the excellence of their Mathematics assessment tools and entrepreneurial skills development systems. Life experiences that are acquired through education and Mathematics in particular for entrepreneurial skills development hang on a good teaching method, interest of students' at school work and finance without which the objectives and policies infringed in the National Policy on Education (Federal Government of Nigeria, 2006) will not be achieved. The lecture method has not been able to visualize complex and abstract concepts that bring about students' development nor will corruption improve the implementation of developmental programs. However, Mathematical strategies like doing it yourself approach, project approach, concrete manipulative approach and video assistant approach among others are the areas this study seeks to find out if they can assist students improve in their entrepreneurial skills.

Taking footballing as a good entrepreneurial skill at the secondary school level, one, it creates the interest, unity, psyche and team work required for a good student academic performance. Two, all activities carried out as footballing are mathematically inclined. Be it in terms of accuracy, speed, time usage and geometric application among others. Students who engage in training themselves on footballing as an enterprise are very sure of getting the desired fulfillment required in living in their life time. Another example of entrepreneurship that is full of mathematical tools for assessing entrepreneurial skills development is that of handset business. From recharge cards selling to the intricacies of the operations of the handsets are full of mathematical calculations and applications.

Assessment on the other hand is the process of gathering information using various methods to systematically gauge the effectiveness of the institution and academic programs to document student learning, knowledge, behaviors, and skills as a result of their collegiate experiences. There are many instruments available to assess student learning. There are direct and indirect measures. Direct assessments are techniques that require students to demonstrate knowledge and skills in a particular area. Alternatively, indirect assessment techniques ask students to reflect on their institution and academic programs and indicate if they believe they have learned and changed as a result of undertaking that course. This paper therefore focused on the use of mathematics as an assessment tool for the practical ways of improving the entrepreneurial skills position of the secondary school students' in Benue State.

\section{Statement of the Problem}

Mathematics is an important human endeavour and has many educational values apart from its technological importance. First, it offers a vast number of structure such as numbers, algorithms, shapes, ratios, functions and data that are useful in sympathetic physical reality. Secondly, mathematics is a human activity built upon intuitive understandings and agreed conventions that are not eternally fixed and that its frontier is covered by many unanswered questions. Thirdly, mathematics encourages settling arguments by evidence and proof. Finally, mathematics demonstrates how important it is to subject a familiar thing to detailed study and to study something that seems hopelessly intricate (Becker 2005).

Since entrepreneurial skills development is the process of identifying, developing and bringing a vision or an idea for living and assessment is the process of gathering information using various methods to systematically gauge the effectiveness of the school and academic programs to document student learning, knowledge, behaviors and skills, can mathematics be a good form of assessment tool for the development of entrepreneurial skills? This is the problem of the study.

\section{Purpose of the Study}

The purpose of the study was to investigate Mathematics as an assessment tool for the development of entrepreneurial skills in secondary schools in Benue State. Specifically, the study seeks to: 
1. Determine the extent to which Mathematics as an assessment tool is used for the development of entrepreneurial skills in secondary schools in Benue State

2. Ascertain how often students use Mathematical strategies to assess the development of entrepreneurial skills in secondary schools in Benue State.

\section{Research Questions}

The following research questions were raised to guide the study:

1. To what extent is mathematics as an assessment tool used for the development of entrepreneurial skills in secondary schools in Benue State?

2. How often do students use the Mathematical strategies to assess the development of entrepreneurial skills in secondary schools in Benue State?

\section{Hypotheses}

The following hypotheses were formulated for the study and tested at 0.05 level of significance

1. Mathematics as an assessment tool for the development of entrepreneurial skills is not significant

2. Mathematical strategies that are used to assess the development of entrepreneurial skills of secondary school students' is not significant

\section{Methodology}

The study employed survey research design. The design is considered most appropriate because variables (mathematics tools and entrepreneurial skills development) according to Ali \& Denga (1989) lends' itself to the use of measurement materials, which yield precision and objectivity. The population of the study consisted of all senior secondary school two students in Benue State. The total sample of this study consists of 208 students drawn using Krejcie \& Morgan (1970) table for determining sample size. First of all, simple random sampling technique was used to select two Local Government Areas (LGAs) from each of the three educational zones of the state using hat and draw procedure. The six LGAs sampled were Ushongo, Ukum, Tarka, Buruku, Ogbadibo and Obi from which were selected six schools. The schools had a total population of 44, 47,36,31,41 and 35 students' respectively. These populations had sampled students of 40, 40, 32, 28, 36 and 32 students' in line with Krejcie \& Morgan (1970) table for determining sample size respectively. This sample size was considered appropriate because literature reviewed that survey design is more easily controlled when the number of respondents in the study are few (Egunjobi, 2002). The instrument for data collection is a self-structured questionnaire titled: Responses to Mathematics as an Assessment Tool for the Development of Entrepreneurial Skills (RMATDES) for the students. Two research questions were raised and two hypotheses were formulated to guide the study. The research questions were answered using the mean scores while the hypotheses were tested at 0.05 level of significance using chi-square statistical tool. A decision mean of 3 was set for the means as the decision point. This is because a five point Likert scale is adopted. That is $5+4+3+2+1=15.15 / 5=3$. A mean score below 3 is considered as low extent while any mean score equal to 3 or above 3 is considered as 'high extent for part B items while for part $\mathrm{C}$ any mean score below 3 is considered as 'sometimes' while any mean score equal to 3 or above 3 is considered as occurring 'often'. For the hypotheses, if the p-value obtained is greater than 0.05 significant level, the null hypothesis is retained and in the alternative, if the p-value obtained is less than or equal to 0.05 significant level, the null hypothesis was rejected.

\section{RESULTS AND DISCUSSION}

Research Question 1: To what extent is Mathematics as an assessment tool used for the development of entrepreneurial skills? 
International Journal of Science and Management Studies (IJSMS)

DOI: $10.51386 / 25815946 /$ ijsms-v3i6p102

\section{www.ijsmsjournal.org}

Table 1: Mean Scores of Students' Response on the Extent to which Mathematics is used in the Development of Entrepreneurial Skills

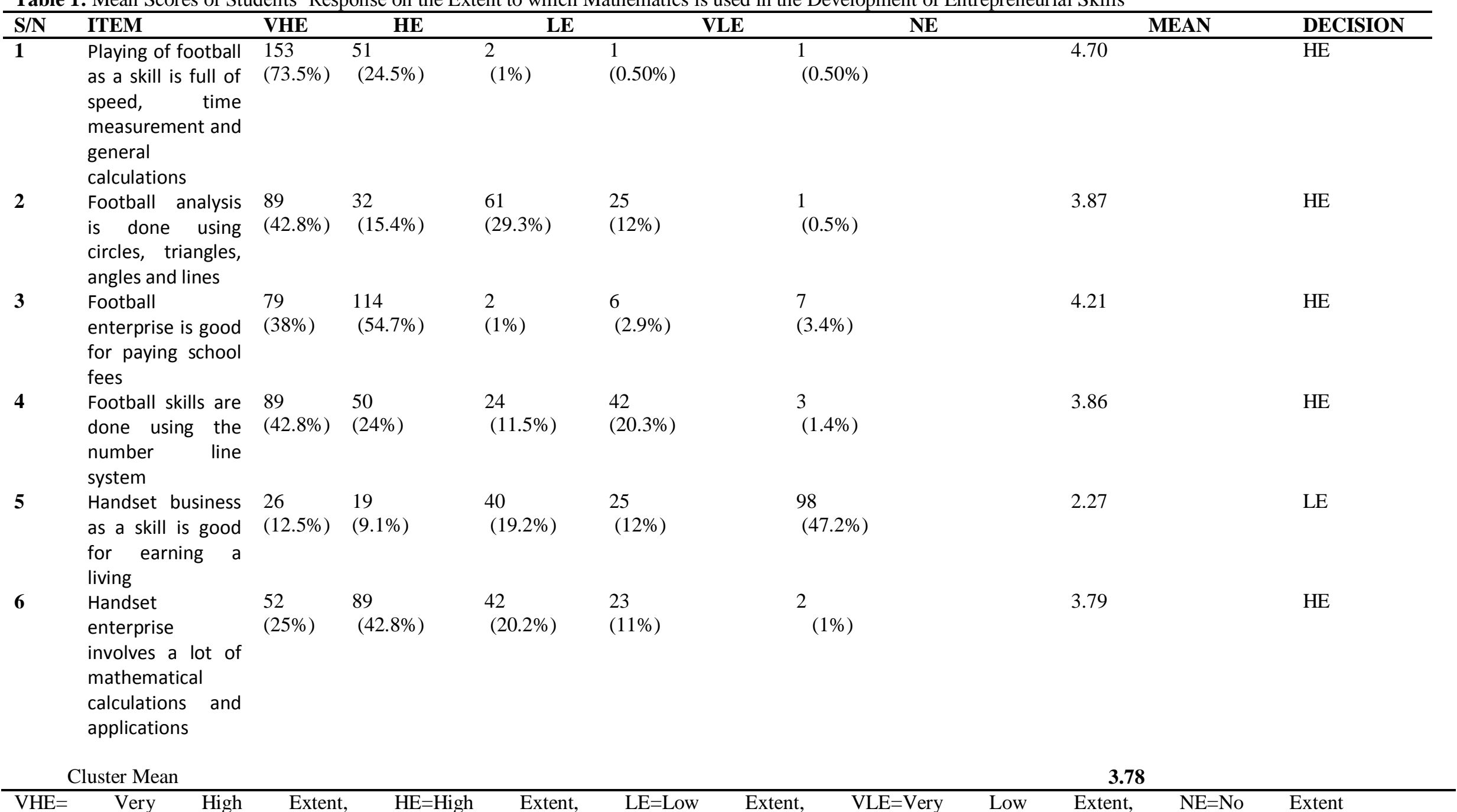


Table 1 shows that items 1, 2, 3, 4 and 6 have mean scores of 4.70, 3.87, 4.21, 3.86 and 3.79 that are equal or greater than the decision mean of 3 while items 5 have a mean score of 2.27 that is less than the decision mean of 3 respectively. The cluster Mean of 3.78 was also greater than the decision mean of 3 . To find out if the difference in means was statistically significant, hypothesis one was therefore tested.

Hypothesis 1

Mathematics as an assessment tool for the development of entrepreneurial skills is not significant

Table 2: Chi-square $\left(\boldsymbol{X}^{2}\right)$ Analysis of respondents on mathematics as an assessment tool for the development of entrepreneurial skills

\begin{tabular}{lllllll}
\hline Opinion & $\begin{array}{l}\text { Observed } \\
\text { Freq. }\end{array}$ & $\begin{array}{l}\text { Expected } \\
\text { Freq. }\end{array}$ & Df & $\boldsymbol{X}^{2}$ & P-value & Decision \\
\hline $\begin{array}{l}\text { Very High } \\
\text { Extent }\end{array}$ & 488 & 1248 & 20 & 779.116 & 0.001 & Significant \\
High Extent & 355 & 1248 & & & \\
Low Extent & 171 & 1248 & & & \\
$\begin{array}{l}\text { Very Low } \\
\text { Extent }\end{array}$ & 122 & 1248 & & & \\
No Extent & 112 & 1248 & & & \\
\hline $\mathrm{P} \leq 0.05$ & & & & & \\
\end{tabular}

Results from table 2 shows a chi-square value of 779.116 at 20 degree of freedom which is significant. This is because the p-value of 0.001 is less than 0.05 . The null hypothesis is therefore rejected. This implies that Mathematics as an assessment tool is useful for the development of entrepreneurial skills in secondary schools in Benue State.

Research Question 2: How often do students use the Mathematical strategies that are used to assess the development of entrepreneurial skills in secondary schools in Benue State? 
International Journal of Science and Management Studies (IJSMS)

DOI: $10.51386 / 25815946 /$ ijsms-v3i6p102

Volume: 3 Issue: 6

November to December 2020

www.ijsmsjournal.org

Table 3: Mean Scores of Students' Response on the Mathematical Strategies that are used to assess the Development of Entrepreneurial Skills

\begin{tabular}{|c|c|c|c|c|c|c|c|c|}
\hline $\mathbf{S} / \mathbf{N}$ & ITEM & VO & $\mathbf{O}$ & ST & $\mathbf{S}$ & DNA & MEAN & DECISION \\
\hline 1 & $\begin{array}{l}\text { Doing-it-yourself } \\
\text { approach is the } \\
\text { best way to } \\
\text { teach/learn } \\
\text { mathematics for } \\
\text { entrepreneurial } \\
\text { skills } \\
\text { development }\end{array}$ & $\begin{array}{l}25 \\
(12 \%)\end{array}$ & $\begin{array}{l}84 \\
(40.4 \%)\end{array}$ & $\begin{array}{l}72 \\
(34.5 \%)\end{array}$ & $\begin{array}{l}24 \\
(11.5 \%)\end{array}$ & $\begin{array}{l}3 \\
(1.4 \%)\end{array}$ & 3.50 & $\mathrm{O}$ \\
\hline 2 & $\begin{array}{l}\text { Concrete } \\
\text { Manipulative } \\
\text { Approach is a } \\
\text { student centered } \\
\text { way of doing } \\
\text { Mathematics }\end{array}$ & $\begin{array}{l}25 \\
(12 \%)\end{array}$ & $\begin{array}{l}105 \\
(50.5 \%)\end{array}$ & $\begin{array}{l}42 \\
(20.2 \%)\end{array}$ & $\begin{array}{l}32 \\
(15.4 \%)\end{array}$ & $\begin{array}{l}4 \\
(1.9 \%)\end{array}$ & 3.55 & $\mathrm{O}$ \\
\hline 3 & $\begin{array}{l}\text { Video Assistant } \\
\text { approach }\end{array}$ & $\begin{array}{l}25 \\
(12 \%)\end{array}$ & $\begin{array}{l}37 \\
(17.8 \%)\end{array}$ & $\begin{array}{l}72 \\
(34.6 \%)\end{array}$ & $\begin{array}{l}25 \\
(12 \%)\end{array}$ & $\begin{array}{l}49 \\
(23.6 \%)\end{array}$ & 2.82 & ST \\
\hline 4 & $\begin{array}{l}\text { Abstract way of } \\
\text { teaching/learning } \\
\text { mathematics for } \\
\text { entrepreneurial } \\
\text { skills } \\
\text { development is } \\
\text { good }\end{array}$ & $\begin{array}{l}98 \\
(47.1 \%)\end{array}$ & $\begin{array}{l}37 \\
(17.8 \%)\end{array}$ & $\begin{array}{l}30 \\
(14.4 \%)\end{array}$ & $\begin{array}{l}18 \\
(8.7 \%)\end{array}$ & $\begin{array}{l}25 \\
(12 \%)\end{array}$ & 3.79 & $\mathrm{O}$ \\
\hline 5 & $\begin{array}{l}\text { Lecture method } \\
\text { impact a lot of } \\
\text { mathematics } \\
\text { knowledge } \\
\text { students' }\end{array}$ & $\begin{array}{l}25 \\
(12 \%)\end{array}$ & $\begin{array}{l}37 \\
(17.8 \%)\end{array}$ & $\begin{array}{l}72 \\
(34.6 \%)\end{array}$ & $\begin{array}{l}37 \\
(17.8 \%)\end{array}$ & $37 \quad(17.8 \%)$ & 2.88 & ST \\
\hline 6 & $\begin{array}{l}\text { The use of Project } \\
\text { Method }\end{array}$ & $\begin{array}{l}37 \\
(17.8 \%)\end{array}$ & $\begin{array}{l}25 \\
(12 \%)\end{array}$ & $\begin{array}{l}18 \\
(8.7 \%)\end{array}$ & $\begin{array}{l}25 \\
(12 \%)\end{array}$ & $\begin{array}{l}103 \\
(49.5 \%)\end{array}$ & 2.36 & ST \\
\hline \multicolumn{4}{|c|}{ Cluster Mean } & & & \multicolumn{3}{|c|}{3.15} \\
\hline
\end{tabular}


Table 3 shows that items 1,2 and 4 have mean scores of 3.50, 3.55 and 3.79 that are equal or greater than the decision mean of 3 while items 3,5 and 6 have mean scores of 2.82, 2.88 and 2.36 that are less than the decision mean of 3 respectively. The cluster Mean of 3.15 was also greater than the decision mean of 3 . To find out if the difference in means was statistically significant, hypothesis two was therefore tested.

Hypothesis 2

Mathematical strategies that are used to assess the development of entrepreneurial skills of secondary school students' is not significant

Table 4: Chi-square $\left(\mathcal{X}^{2}\right)$ Analysis of Respondents on Mathematical Strategies that are used to Assess the Development of Entrepreneurial Skills

\begin{tabular}{lllllll}
\hline Opinion & $\begin{array}{l}\text { Observed } \\
\text { Freq. }\end{array}$ & $\begin{array}{l}\text { Expected } \\
\text { Freq. }\end{array}$ & Df & $\boldsymbol{X}^{2}$ & P-value & Decision \\
\hline Very High & 235 & 1248 & 20 & 458.015 & 0.001 & Significant \\
Extent & & 1248 & & & & \\
High Extent & 325 & 1248 & & & \\
Low Extent & 306 & 1248 & & & \\
Very Low & 161 & 1248 & & & \\
$\begin{array}{l}\text { Extent } \\
\text { No Extent }\end{array}$ & 221 & & & & \\
\hline P $\leq 0.05$ & &
\end{tabular}

$\mathrm{P} \leq 0.05$

Results from Table 4 shows a chi-square value of 458.015 at 20 degree of freedom which is significant. This is because the p-value of 0.001 is less than 0.05 . The null hypothesis is therefore rejected. This implies that Mathematical strategies that are used have a significant influence in assessing the development of entrepreneurial skills of secondary school students' in Benue State.

\section{Discussion}

The first finding of this study is that Mathematics as an assessment tool is useful for the development of entrepreneurial skills in secondary schools in Benue State. This is reflected in the result of the research which shows that in most of the responses, students' believe that mathematical shapes like circle, triangles, angles and lines are often used in virtually everything they do on a daily basis. Others daily uses of mathematics include the use of numbers, time and general calculations. This is in line with Omenka, (2013) who reported that mathematics as a key element and activity in the day to day living that every human being practice in one form or the other is a subject which consists of facts, concepts and entrepreneurial skills which every person whether a layman or business man should know. The concept of the number system is so fundamental that in our daily lives that no normal human being can function without is noted also by scholars.

The second finding of this study is that Mathematical strategies that are used in teaching and learning Mathematics for entrepreneurial skills development are significant. Doing-it-yourself approach as a way of learning Mathematics by students' is considered in this study as the best approach for assessing entrepreneurial skills at the secondary school level. This implies that instead of letter grades, different business done by students came up as a measure for performance.

The study revealed that the present lecture method adopted by many teachers in preparing students for life entrepreneurship has failed. That when student at this age are given skills to practice themselves, the adage that says practice makes perfect will become a reality when they are old. This is in line with Wever, Iorshal, and Ademu, (2013), who are of the view that integrating entrepreneurship education in secondary schools education curriculum will sustain development of entrepreneurial skills and make students self reliance. 
Again, the findings reviewed that among the various skills, others are stills higher than the rest in terms of their Mathematical involvement. This finding agrees with that of Becker (2005) that Mathematics demonstrates how important it is to subject a familiar thing to detailed study and to study something that seems hopelessly intricate. That on less you dig up the intricacies, one is bound to fail in entrepreneur skills development.

\section{Conclusion}

Based on the results of this study, it has been established that mathematics is an assessment tool for the development of entrepreneurial skills in senior secondary schools in Benue State. That when students at younger ages are given skills to practice themselves, the adage that says practice makes perfect will become a reality when they are old, they will become great business tycoons. It is also concluded that this new measure of performance will create jobs (businesses) faster than the letter grading (certificate) measure of lecture method.

\section{Recommendations}

Based on the findings, the following recommendations are made:

1. Student' should be made to relate mathematics with business activities with a view to accepting it as a tool for assessing entrepreneurial skills.

2. Doing-it-yourself-Learning approach should be introduced at the secondary school level.

3. Teachers of mathematics should recognize and realize the special role entrepreneurial skills play in secondary school students' to tailor their work in such a way as to catch them young for a future entrepreneurial nation.

\section{References}

[1] Becker, J. R. (2005). Differential treatment of females and males in mathematics classes Journal of Research in Mathematics Education 12 (3), $40-53$

[2] Federal Republic of Nigeria, (2006). National Policy on Education (Revised), Yaba: NERC Press.

[3] Omenka, J.E. (2013), Impact of Ethno-Mathematics on Students' Mathematics Achievement in Junior Secondary Schools in Benue State: African Journal of Arts, Science and Educational Issues 1(1) 9-16

[4] Wever, D. G., Iorshal, M.W. \& Ademu, A. (2013). Integrating Entrepreneurship Education in Secondary School Education Curriculum for Sustainable Development and Self Reliance: African Journal of Arts, Science and Educational Issues 1(1) 99-104

[5] Zuamo, J.T, and Aondoakaa, E.K. (2007), Basic Entrepreneurial Skills, Makurdi: Traeces Nig. Ltd. 